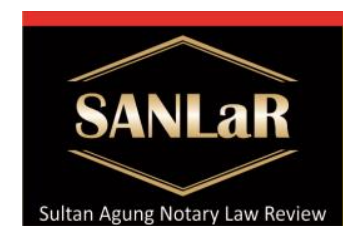

\title{
Implementation of Transfers of Sale and Purchase Rights to Freehold Land and Registration
}

\author{
Anggri Rizky Pradhani *) \\ ${ }^{*}$ Notary Public of Cirebon, and Student of Master of Notary Law, Faculty of Law, \\ Universitas Islam Sultan Agung Semarang, Indonesia, E-mail: \\ anggririzky1992@gmail.com
}

\begin{abstract}
This study aims to: 1) To find out the procedures and procedures for the sale and purchase of freehold land and its registration at the Cirebon City Land Agency Office. 2) Obstacles that occur in the registration of the transfer of sale and purchase of property rights at the Cirebon City Land Agency Office. The approach method used in this research is the juridical empirical legal approach method. Research using the empirical juridical legal method is also called legal research regarding the enactment or implementation of normative legal provisions in action on any particular legal event that occurs in society. Based on the results of the data analysis, it is concluded that: 1. To make it easier to carry out legal actions of transferring property rights which are the objects of transfer to the right recipient, the transfer of rights must be carried out before the Land Deed Making Official who makes the deed and registered at the Land Office. In making a deed of sale and purchase of land rights, the seller, the buyer and witnesses must attend. Two pieces of land deeds issued by PPAT are made, all of which are original. One sheet is kept at the PPAT Office, the other sheet is submitted to the Head of the Land Office for registration purposes. The parties were only given a copy. 2. Obstacles originating from internal factors, causing the community to feel disappointed because the registration service for the transfer of land rights seems slow, While the obstacles originating from external factors, there are still many people who do not make the transfer of their land rights before the PPAT and at the same time do not register the transfer at the Land Office.
\end{abstract}

Keywords: Sale and Purchase Implementation; PPAT; Land Registration.

\section{Introduction}

Soil is one of the important factors in human life. Both as a source of life and as a means for physical development to be used for the greatest prosperity of the people. Especially in Indonesia, where most of the population makes a living in the vicinity of agriculture. Function land is so important and has its own meaning, because land is the capital for the life of a family. In addition, land is always used for various human activities, such as a place to live, build a building, and even 
people need land.

There is a close relationship between humans and the land, because land is a foothold and carries out daily life. So humans are competing to control and own the land they want because land has economic value for all aspects of human life. To create the

prosperity and welfare of the people as desired by the Indonesian people, problems related to the use, ownership of control and transfer of land rights require special attention in statutory regulations.

Recognizing the expanding community activities in various fields and the increasing population and human need for land, the position of land is very important, especially in control, use and ownership.

In particular, this is the more advanced economic activity, the more land is involved in it, the expansion of that activity which generally takes the form of an increase in buying and selling, leasing, inheriting, extending credit and even establishing legal relationships with foreign persons or legal entities.

This fact shows that the position and role of land rights in Indonesian society is very important. Because of the importance of the position and role of land, it often creates problems. Like building housing in green belt areas, absent land ownership, double certificates. Therefore, efforts to overcome problems in the land sector are by providing legal guarantees and certainty of rights in the land and agrarian sector.

The basic foundation for the government and the people of Indonesia to formulate legal politics and policies in the land sector as stipulated in the 1945 Constitution Article 33 paragraph (3) which reads as follows: "The land, water and natural resources contained therein are controlled by the state. and used for the greatest prosperity of the people ". This provision is spelled out in Article 2 of the Basic Agrarian Law which states that "Earth, water and space, including the natural resources contained therein, are at the highest level controlled by the 
state as an organization of power for all the people". ${ }^{1}$ In order for the holder of ownership rights to land to prove that he is the holder of the right of ownership over the land or in other words for the realization of legal certainty, the holder of a freehold title is obliged to register their rights and transfers. In connection with the transfer of ownership rights to land Article 37 paragraph (1) Government Regulation Number 24 of 1997 stipulates that:

1. Transfer of land rights and ownership rights to apartment units through sale and purchase, exchange, grants, income in companies and other legal acts of transfer of rights, except the transfer of rights through auction can only be registered if it is proven by deeds made by the authorized PPAT according to the provisions. prevailing laws and regulations. This provision implies that the transfer of land rights due to a legal act (sale and purchase) can be registered if it is proven by a PPAT deed. The PPAT deed is evidence that there has been a transfer of land rights due to legal action through sale and purchase and one of the absolute conditions for registering the transfer of ownership rights due to buying and selling at the Land Office.

2. Based on the description of the author above, the authors are interested in conducting legal research with the title "IMPLEMENTATION OF SALE AND BUY PROPERTY RIGHTS TO LAND AND REGISTRATION".

\section{Research Methods}

The approach used in this study is a juridical empirical legal approach. Research with the empirical juridical legal method is also called legal research regarding the enactment or implementation of normative legal provisions in action at any particular legal event that occurs in society. This means to describe and explain the data obtained from the research results clearly regarding the implementation registration

\footnotetext{
${ }^{1}$ http://www.lawskripsi.com/index.php?option=com content\&view=article\&id=113\&ltemid=113Prof
} 
of transfer of sale and purchase of land ownership rights and any obstacles that occur in registration. ${ }^{2}$

\section{Results and Discussion}

3.1 Procedures and procedures for the sale and purchase of freehold land and registration at the Cirebon City Land Agency Office.

When we want to buy land and buildings, of course we have to pay attention to many things, starting from price, location, conditions, and most importantly we need to pay attention to the terms and procedures for buying and selling land and buildings that are legal, especially proof of purchase to indicate that the object has switched, as well as also for buying and selling land and buildings. The sale and purchase of land or house is proven by a Deed of Sale and Purchase of land and buildings or abbreviated as AJB. AJB is made by the parties at the Office of the Official for Making Land Deeds (PPAT). The sale and purchase of land must be clear and in cash, that is, it must be in the presence of PPAT and must be paid in full, otherwise the AJB cannot be made. Before PPAT makes AJB, PPAT will provide an explanation of the procedures and requirements that need to be completed by sellers and buyers.

1. Inspection of Certificates and Receipt of PBB PPAT will conduct an inspection of land rights certificates. The examination is carried out to match the data between the certificate and the Land Book at the Land office, to ensure that the land is not involved in legal disputes, is not being secured, and is not in confiscation. PPAT also checks Land and Building Tax or PBB. PPAT also checks the PBB Deposit Receipt or STTS PBB to ensure that the land is not in arrears for PBB payment.

2. Approval of Husband and Wife If the seller is married, the land and buildings will become joint assets, so the sale of the land must be based on the husband / wife's consent by signing a letter special approval, or co-sign

\footnotetext{
${ }^{2}$ Lexy J. Moleong, Metodologi Penelitian Kualitatif, (Bandung: PT Remaja Rosdakarya, 2006).
} 
the AJB. If the husband or wife has died, this can be done by attaching a death certificate from the village office.

3. Tax fees and making AJB The seller must pay building income tax (BPHTB), with the following conditions:

- Seller Tax $(\mathrm{PPh})=$ Selling Price $\times 2.5 \%$

- Buyer Tax $($ BPHTB $)=\{$ Selling Price - Non-Taxable Value $\} \times 5 \%$

- Buyer and Seller pay for PPAT services which generally will be borne jointly or if both parties agree to be borne by one of the parties.

4. Preparation and Signing of AJB PPAT reads and explains the contents of the AJB. If the seller and the buyer agree to the contents of the $A J B$, then the AJB is signed by the seller, buyer, witness and PPAT. Once signed, AJB is printed. The original printed AJB is made for safekeeping by PPAT and submitted to the defense office for the purpose of transferring names, while the seller and the buyer will get a copy of the AJB.

5. The process of changing the name at the land office After the AJB is signed, the new certificate can be reversed from name to name of the buyer. The files that need to be submitted for the name transfer process include:

1) Buyer Documents

- Photocopy of Identity Card

- Photocopy of Family Card Photocopy

- Marriage Certificate (if married)

- Photocopy of NPWP

- Proof of full payment of BPHTB

- A letter of request for a name transfer signed by AJB from the PPAT

2) Seller Documents 
- Photocopy of Identity Card

- Photocopy of Family Card

- Photocopy of Marriage Certificate

- Land Rights Certificate

- Proof of payment of PPh. ${ }^{3}$

In the case of making a PPAT deed, one of the steps that must be carried out by PPAT is:

1. Before a deed is drawn up regarding the transfer of title to land, the prospective buyer or right recipient must make a statement stating: ${ }^{4}$

a. That those concerned with the transfer of rights do not become holders of land rights that exceed the maximum provisions for land tenure according to the provisions of the prevailing laws and regulations;

b. That those concerned with the transfer of rights are not the holders of absentee land rights (guntai) according to the provisions of the prevailing laws and regulations;

C. That the person concerned is aware that if the statements referred to in $a$ and $b$ are not true, the excess land or absentee land becomes the object of land reform;

d. That the person concerned is willing to bear all the legal consequences, if the statements as referred to in $a$ and $b$ are not true.

PPAT is obliged to explain to the prospective buyer or right recipient the intent and contents of the statement as referred to above.

\footnotetext{
${ }^{3}$ https://jendela360.com/info/syarat-jual-beli-tanah/.

${ }^{4}$ Article 99 Regulation of the State Minister for Agrarian Affairs / Head of the National Land Agency Number 3 of 1997 concerning Provisions for Implementing Government Regulation Number 24 of 1997 concerning Land Registration.
} 
2. The PPAT Deed must be read / explained to the parties in the presence of at least 2 (two) witnesses before being signed immediately by the parties, witnesses and PPAT, as stipulated in Article 22 of Government Regulation Number 37 of 1998 concerning Position Regulations. Land Titles Registrar.

3. Not later than 7 (seven) working days from the signing date of the deed concerned, PPAT

is obliged to submit the deed it has drawn up and the documents concerned to the Land Office tobe registered.

\subsection{Obstacles that occur in the registration of the transfer of sale and purchase of} property rights at the Cirebon City Land Agency Office.

Related to the making of deeds that are not made in accordance with the formal terms and conditions for the making of this deed constitute the inadequacy of PPAT in making the deed, because in fact the PPAT deed has been provided in a blank form by the National Land Agency and PPAT is only given the task to fill it in with data regarding the legal action of transferring rights to land these include, among other things, the subject and the object as well as ensuring the date of making / signing the deed, the correctness of the parties' signatures including the contents of the deed after reading the contents of the deed to the parties. ${ }^{5}$

As an authentic deed, the PPAT deed functions as a perfect proof power that can be degraded into the power of proof to become like an underhand deed. Degradation of the strength of authentic deed evidence to under-hand evidence, and juridical defects of authentic deeds which result in authentic deeds being canceled or null and void, occur if there is a violation of statutory provisions.

The procedure for issuing a PPAT deed as an authentic deed is very decisive, therefore if an interested party can prove that there is a defect in its form due to an error or discrepancy in the procedure for its preparation, there will be risks for the certainty of rights that arise or are recorded on the basis of the deed. In addition, as a result of not fulfilling the formal requirements, the legal and juridical consequences that arise are the possibility of a lawsuit from the parties or the registration of the transfer of rights has just arrived at the Land Office service counter and the examining officer has stated that the application file is rejected and needs to be completed.

In accordance with Government Regulation Number 24 of 1997 concerning registration of transfer of land rights, agencies and officials have been appointed and assigned the

\footnotetext{
${ }^{5}$ Interview with Sari Nurulita, SH., MKn, Cirebon City Land Deed Maker, on July 11, 2020.
} 
task and authority to carry out registration services for the transfer of land rights, including the methods taken for each applicant as well as the conditions that must be met in obtaining a right to the land he owns. The time for completing the registration of the transfer of land rights for certified freehold land is around 11-20 days.

But in reality, the time taken to complete this was up to months. This is because in its implementation there are various kinds of obstacles that cause the registration of the transfer of land rights to be completed inappropriately on time, both from internal and external factors.

Obstacles originating from internal factors, causing the community to feel disappointed because the registration service for the transfer of land rights seems slow, does not match the predetermined time and takes a longer time than it actually is.

While the obstacles originating from external factors, there are still many people who do not make the transfer of their land rights before the PPAT and at the same time do not register the transfer at the Land Office. The obstacles that occur include:

1. Constraints arising from internal factors, in this case the Semarang City Land Office. The obstacles that exist in the Land Office can be divided into two, namely obstacles in the technical or implementing aspects and obstacles in the aspect of bookkeeping.

a.

Barriers in technical or implementing terms, meaning obstacles seen from the perspective of the implementer, in this case related to human resources, including:

a) Lack of human resources, in this case experts in the land sector, who handle the registration of the transfer of land rights in the Sub-Section of the transfer of assignment rights and PPAT. The implementation of registration services for the transfer of land rights is not an easy task but it is a tough job that requires a lot of experts in their fields. In the Land Office, the number of experts who handle the registration of transfer of land rights because this sale and purchase is still very limited. This can be seen from the accumulation of registration work for this transfer of land rights, which causes this service is very slow and not on time. Likewise for the measuring officer, if the land transferred has not been certified, even though there is already a 
scheduled surveying officer, it is often too late to take measurements, because the number of measuring workers is very limited. This delay is due to the large number of work of measuring officers who are more important than field measurements, which ultimately results in delayed measurement work.

b) Conflict of interests of employees between work interests and personal interests, both of which are equally important. The lack of experts in this work has resulted in a conflict of interest between the personal interests of employees and work interests, both of which are perceived to be important. This also causes the implementation of the registration of the transfer of land rights to not run smoothly, and hinders the completion time.

c) The Head of the Land Office is busy. The work of the Head of the Land Office is very solid. His busy life sometimes puts off this work for some time, because he feels that there is something of interest that must be resolved first, which is very important from other jobs.

b. In terms of bookkeeping, this means obstacles seen in terms of bookkeeping or recording, including:

a). Search for land books that were not found When PPAT is about to register the transfer of land rights, it must first look for a land book that is in accordance with the certificate concerned, to find out whether the data in the certificate match the data in the land book. concerned at the same time to record the transfer and abolition of land rights, especially due to sale and purchase. In the search for the land book, sometimes there are obstacles, including not finding the land book in the archive of land books, this is because the land book in question is being used / used by another division and has not been returned to the cupboard of the land book archive. This resulted in a delay in matching and recording in the land book regarding the transfer of land rights, because it was waiting for the land book to be processed by 
another division. Likewise, the land book that was to be used was lost. The loss of this land book at the Land Office could also be due to the irregularity of the employees in saving the land book back in the archive cupboard or the land book that has become obsolete by time. Where the loss of the land book must go through an official report of the loss, to make a new land book again, which takes a very long proceses.

b). The filling of deeds, especially the sale and purchase made by the PPAT, are incomplete, inaccurate and tend to be imperfect in making the deeds. This lies in the number of pages containing articles in the sale and purchase deed that are unused, not written down. In each amendment / addition to the sale and purchase deed, the PPAT or the parties do not initial it and do not affix the PPAT stamp. So it must be returned to the relevant PPAT, to complete it immediately. This is what causes the implementation of the registration of the transfer of land rights to be delayed and seems very slow.

c). The documents required to register the transfer of land rights due to the sale and purchase are incomplete or incomplete. This can be seen from the photocopy of the KTP which is no longer valid or has not been legalized by the competent official, as well as certificates for which rights are transferred have not been checked first at the office.

Where the certificate is checked by PPAT before making the land sale and purchase deed. This incomplete file will be returned to the applicant to be completed first. This will prolong the registration period for the transition so that it appears that the implementation is very slow.

d). The land which will be registered for the transfer is in fact in a dispute. In this case, the Land Office refuses to register the transfer because of the sale and purchase, as long as the land is still in dispute with another party.

Factors that hamper the implementation of sale and purchase deed registration at the Land Office are: 
1. There is misinformation on the part of the applicant. The misinformation provided by the applicant was due to the lack of proactiveness of the community as the applicant to come directly to the land office to ask what are the administrative requirements that must be prepared in the initial process of land registration, so that most of the people who come to register their land have administrative requirements. which must be fulfilled is incomplete so that the files are returned and not further processed by the committee for the inspection of the files. Initial misinformation provided also sometimes occurred from the land office, This occurs due to the lack of socialization with community counseling so that the information obtained by the applicant is lacking which results in when the applicant registers his land, the administrative files submitted by the applicant are incomplete. This is the basis of the incomplete information provided by the land office.

2. There are objections / objections from other parties during the land registration process. Rebuttal / objections from other parties are because the land registered by the applicant is disputed land so that at the time of the process the land was not continued by the committee that carried out the measurement and mapping, it is returned to the applicant to resolve the land dispute and if the land dispute dispute has been resolved, the committee will resume the measurement and mapping that had been carried out. ${ }^{6}$ However, sometimes what happens when a dispute over land rights has been completed by the applicant, what should be continued is the registration procedure. However, the applicant must register again from the initial stage of land registration. The applicant uses the services of another person.

3. The applicant uses the services of other people (brokers) because the applicant does not want to be difficult in terms of administrative management so that they use the services of other people, this is because the applicant only wants convenience without having to go back and forth to the

${ }^{6}$ ibid 
land office to register his land. The use of other people's services is due to complicated administrative procedures at registration, which causes the applicant to immediately complete the process by using the services of brokers. The use of brokerage services also has consequences, such as fees outside registration. ${ }^{7}$

With various problems that arise in registering the transfer of property rights that occur due to various factors, there are several efforts made by the PPAT and the Land Office to minimize these obstacles which are routinely carried out by the Land Office. Efforts to reduce these barriers include:

1. From an internal point of view

a) Making announcements to every sub-district in the city / regency area, regarding information both regarding the registration of land ownership rights through sale and purchase as well as land registration for the first time.

b) Always summon every village head / sub-district head for guidance from the Land Agency regarding land registration, so that every village head will always transfer his property through an authorized official to ensure legal certainty.

c) Providing insights to the community through the head of the village regarding information on land registration and the amount of land registration fees will not escape from applicable government regulations.

2. From an external perspective

a. Direct counseling by the Land Office Employees. As mentioned above, the land office in transferring property rights must first conduct socialization to the local village head, and if necessary, there are several land office employees who accompany the village head to socialize the importance of registering the transfer of property rights. Where apart from it is the responsibility of each Village Head to re-

\footnotetext{
${ }^{7}$ Interview with Mr. Setyo Anggraeni, ST, ME, head of the Cirebon City Land Office, on July 14, 2020.
} 
socialize this matter to its citizens, but based on existing data in the field, the comparison of registration of the transfer of property rights carried out by the community between PPAT Head $80 \%$ and PPAT is around $20 \%$.

b. PRONA APBN for the National Agrarian Operation Project (PRONA) came into effect on 15 August 1981 since the issuance of the Minister of Home Affairs Decree No. 189 of 1981. With this PRONA, it is hoped that the land problems that are rife can be resolved with full understanding and awareness from the community.

Providing legal certainty in the land sector requires the availability of written, complete and clear legal instruments which are implemented consistently in accordance with the spirit and content of the provisions so that people take legal actions those concerned with land have guaranteed legal certainty and guaranteed land rights. ${ }^{8}$

Registration here is not a requirement for the transfer of rights because the transfer of rights has occurred after the sale and purchase of rights has been made before the PPAT. Thus the sale and purchase of land is valid and completed with the making of the PPAT deed and the PPAT deed is evidence that a sale and purchase has occurred, namely that the buyer has become the owner and registration of the transfer of rights at the Agrarian Office is not a condition for the validity of the land sale and purchase transaction and registration at here only serves to make evidence against third parties or public.

\section{Closing}

\subsection{Conclusion}

Based on the overall results of the research and discussion as described in the previous chapters, the writer can put forward the following conclusions:

1. That in order to make it easier to carry out a legal act of transferring property rights which becomes the object of transfer to the right recipient,

\footnotetext{
${ }^{8}$ Boedi Harsono, ibid.
} 
then the transfer of rights must be carried out before the Land Deed Making Official who makes the deed and registered at the Land Office. In making a deed of sale and purchase of land rights, the seller, the buyer and witnesses must attend. Two pieces of land deeds issued by PPAT are made, all of which are original. One sheet is kept at the PPAT Office, the other sheet is submitted to the Head of the Land Office for registration purposes. The parties were only given a copy.

2. The obstacles faced by PPAT are related to the Deed of Sale and Purchase that exceeds the stipulated timeframe for the realization of legal certainty and solutions to solve the problem of these obstacles. in this case the Office Land) and barriers from external factors (in this case from society) are:

a. Internal factors, can be divided into 2, namely:

1) The technical aspect (executor), including the lack of human resources / experts, conflict of interests of employees between work interests and personal interests, both of which are equally important, and the busyness of the Head of the Land Office.

2) In terms of bookkeeping, including searching for undiscovered land books, filling in incomplete and incomplete sale and purchase deeds, the documents required are incomplete or incomplete, and the land to be transferred is in a dispute.

b. External factors, in this case from the community itself, include:

1) The number of transfers of land rights that are carried out under the hands of only a stamp duty.

2) The community still lacks knowledge of the importance of registering the transfer of land rights.

3) For rural communities, the cost of transferring land rights until the transfer of rights is registered is very expensive. 
4) Many people in rural areas register their transfer of land rights through the Village Head, which sometimes because of the Village Head's busyness results in the registration of the transfer of land rights being delayed.

In implementing the transfer of land ownership rights at the Land Office there are various good obstacles faced by the Land Office, such as a lack of public awareness, a bad image of BPN and different rights grounds from the data in the field. The problems faced by the community include lack of public understanding, high registration fees and the existence of taxation law investments (BPHTB and other costs). To overcome these obstacles, BPN has developed programs that can support the implementation of land registration such as conducting counseling to the community and through the PRONA program and in collaboration with the City / Regency Industry and Cooperatives Office.

\subsection{Suggestion}

Based on the result research and conclusion in on, then author suggest the following:

1. For PPAT

As a PPAT, in making a sale and purchase deed should always rely on existing provisions because what will be made is an authentic deed which greatly affects the legal certainty of the transfer of land rights. PPAT also needs to better understand the existing provisions to prevent PPAT from being sanctioned by dismissal either with respect or disrespect or demands for compensation from the parties. In carrying out its duties, PPAT must always be based on high morality and integrity towards its profession and position as PPAT.

2. For the parties.

The parties should comply with the correct deed making procedure so as 
to avoid the possibility of threatening the certainty of land rights that are obtained. The parties must be able to cooperate with PPAT in making the sale and purchase deed so that the resulting deed can guarantee the certainty of the rights to the land being traded.

\section{References}

Books:

[1] Lexy J. Moleong, Metodologi Penelitian Kualitatif, (Bandung: PT Remaja Rosdakarya, 2006).

[2] Boedi Harsono, ibid.

Internet:

[1] http://www.lawskripsi.com/index.php?option=com content\&view=article\&id= $\underline{113 \& / \text { temid }=113 \text { Prof }}$

[2] https://jendela360.com/info/syarat-jual-beli-tanah/.

\section{Regulation:}

Article 99 Regulation of the State Minister for Agrarian Affairs / Head of the National Land Agency Number 3 of 1997 concerning Provisions for Implementing Government Regulation Number 24 of 1997 concerning Land Registration.

Interview:

[1] interview with Sari Nurulita, SHMKn, Cirebon City Land Deed Maker, on July 11, 2020.

[2] interview with Mr. Setyo Anggraeni, ST, ME, head of the Cirebon City Land Office, on July 14, 2020. 